\title{
Social Consequences of Vehicle Exhaust: A Case Study in Poltava, Ukraine
}

\author{
Olena Stepova $^{1, *}$, Olena Hanoshenko ${ }^{1}$, Tetyana Serha ${ }^{1}$, Natalia Yesina ${ }^{2}$, Olena Strelnikova
}

\author{
${ }^{1}$ National University "Yuri Kondratyuk Poltava Polytechnic", Poltava, Ukraine \\ ${ }^{2}$ H.S. Skovoroda Kharkiv National Pedagogical University, Kharkiv, Ukraine \\ *corresponding author e-mail: Olena Stepova, alenastepovaja@gmail.com
}

Received: 10 September 2021 / Accepted: 26 November 2021

\begin{abstract}
Intensive urbanization processes, an increase in the number of urban population and transport have led to an increase in the technogenic load on the environment, in particular on the atmospheric air. Among a significant number of sources of environmental pollution, roads and vehicles pose a significant threat. Motor vehicles cause irreparable harm to human health and the environment. Regular assessment of the quality of atmospheric air in residential areas of cities with heavy traffic to establish the level of potential risk to public health is an urgent task. The study purpose is the social consequences of transport emissions; determination of the anthropogenic load on the air and of the indicator of public health risk from the vehicle exhaust impact. The study was carried out on the example of the residential and the most loaded transport area of Poltava (Ukraine). The study demonstrates that the overwhelming majority of the urban population lives in areas where health risk indicators exceed permissible norms. Since the elderly, children and students are most often present on the street and near houses, they are at the greatest risk. The same applies to vehicle drivers who are often idle in "traffic jams". In turn, such high levels of air pollution pose even greater risks to public health, in particular to the development of respiratory diseases. In the study of the peculiarities of Ukrainian legislation in this area, it was established that the mechanism for collecting information about the quality of the environment, however, there is no requirement to inform the population about it.
\end{abstract}

Keywords: urban areas, vehicle exhaust, atmospheric air quality, public health, potential risk.

\section{Introduction}

Air pollution by vehicle exhaust is one of the most dangerous for human health. This is justified by the fact that emissions from road transport fall into the air surface layer, where the human breathing zone is located. At the same time, in the surface layer, there are unfavorable conditions for dispersion, due to the fact that the buildings of residential areas near highways more intensively trap pollutants and prevent them from dispersing. These pollutants are inhaled by the population of this area, as well as deposited on the soil and penetrated into the groundwater (Ziarati et al., 2020; Reşitoğlu et al., 2015).

The characterization of the effects of transport-related pollution on human health in most cases depends on the vehicle exhaust composition, the environmental conditions and the proportion of the exposed population. The latter is determined not only by the width and load of roads, but also by the remoteness of roads from residential buildings.

The rationale for the research topic is that vehicle exhausts are considered the main source of increasing the level of gas pollution, especially in large cities and urban areas with high traffic (Topacoglu et al., 2014; Yadav \& Rawal, 2016). The constantly growing cars number leads to a significant excess of the maximum permissible concentrations (MPC) of pollutants in the troposphere surface layer in the urban territory, negatively affects the population health, namely, it contributes to headaches, weakness, loss of appetite, violation of the cardiovascular and nervous system (Singh, 2020); disrupts the gastrointestinal tract work, respiratory organs, 
eyes mucous membranes, reproductive system (Uhrner et al., 2007; Abdel-Shafy \& Mansour, 2016).

The air pollution level in residential and central areas of cities depends on the number and category of vehicles, the fuel type, the intensity and speed of traffic, the roadways branching, the road surface quality, the number and type of green spaces.

Thus, there is a need to regularly assess the atmospheric air quality in residential areas of cities with heavy traffic in order to establish the level of potential risk to public health.

\section{Materials and Methods}

\section{1 Methodology}

The research methodology is presented in Figure 1 in the form of the structural and logical scheme.

Open sources were studied, namely the current Ukrainian regulatory documents, patents of any country in the world, scientific research presented in high-quality journals, which are indexed in Scopus, Mendeley, PubMed, ScienceDirect, Google Scholar, ResearchGate.

The logical thinking method was used to pose the problem. Using the methods of analysis and synthesis, the features of the methods for assessing the quality state of atmospheric air were studied and compared.

Determination of the anthropogenic load on the air from vehicle exhaust and the indicator of public health risk from the vehicle exhaust impact were carried out using Microsoft Excel in accordance with the methodology "Assessment of atmospheric air pollution in a city area using the atmospheric pollution index (API)", approved in Ukraine (SSR-201$97,2014)$. The study of risk assessment was carried out in accordance with the approved methodology "Assessment of the quality state of atmospheric air by the magnitude of the potential risk to public health" (MR, 2007; OMHU, 2007). It is based on the ratio of the actual concentration of the pollutant in its MPC and the hazard class of the substances. To construct dispersion maps of some harmful substances (carbon oxide, nitrogen dioxide and saturated hydrocarbons) and maps of potential risk to public health,

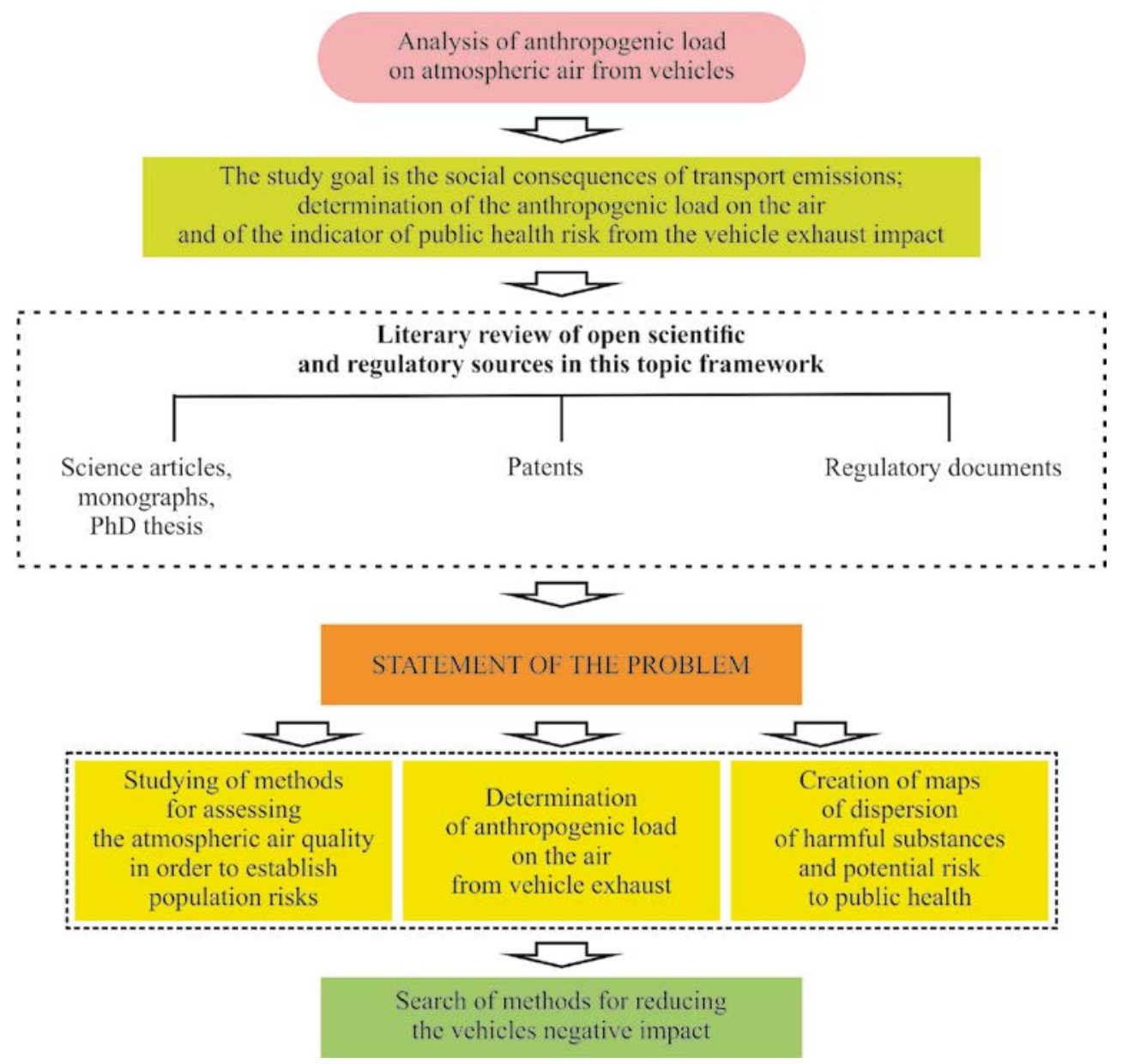

Figure 1. The research methodology 
the software complex EOL-2000 [h] version 4.0 (installation package according to the agreement No. 62 dated June 15, 2021 with SOFT FUND LLC, recommended by the Ministry of Environmental Protection of Ukraine, letter. 2464/19 / 4-10 dated March 15, 2006) was used.

In the study of the search for ways to reduce the negative impact of vehicles at the present stage of the country's development, an analytical review of organizational and engineering solutions for the protection of atmospheric air from vehicle exhaust was applied.

\section{2 Justification of the choice of territory for research and its characteristics}

For the study, an area was chosen that includes the transport and road network and residential quarters of the Shevchenko district of the city of Poltava, located in the south-western part of the city, on the right bank of the Vorskla (which includes the historical centre); the village of Kobischany and Ocheretyanka; partly the territory of the settlements Shcherbani, Rozsoshentsi, Ivanova and Instytutska hora (ShDC, 2017). The choice is based on the fact that this territory is one of the largest and most densely populated areas of the city of Poltava (Fig. 2). The population is 147,600 people (as of January 2018) (SSSU, 2018).
In the central part of the district, multi-storey buildings prevail. In the specific structure of motor transport, cars and light trucks are predominant. The highest traffic flow is observed on the central streets and intercity highways, the lowest - in the so-called "sleeping" areas.

170 roads of the region with the most intensive traffic were studied. For this, a vehicle count was carried out during peak hours 3 times a day. The assessment was carried out according to the arithmetic mean indicator of the intensity of vehicles using approved methods to establish the indicator of pollution and risk to the health of the population. A summary of the intensity of traffic flow and volumetric emissions of the investigated pollutants is given in Annex A.

\section{Results and Discussion}

\subsection{Review of the consequences of chemical constituents impact of emissions from vehicle on human health}

Vehicles, due to the intense emission of combustion products, are one of the main reasons for the constantly growing morbidity rate of the population (Rouleau et al., 2013; Martini et al., 2009; Dean et al., 2019). The transport

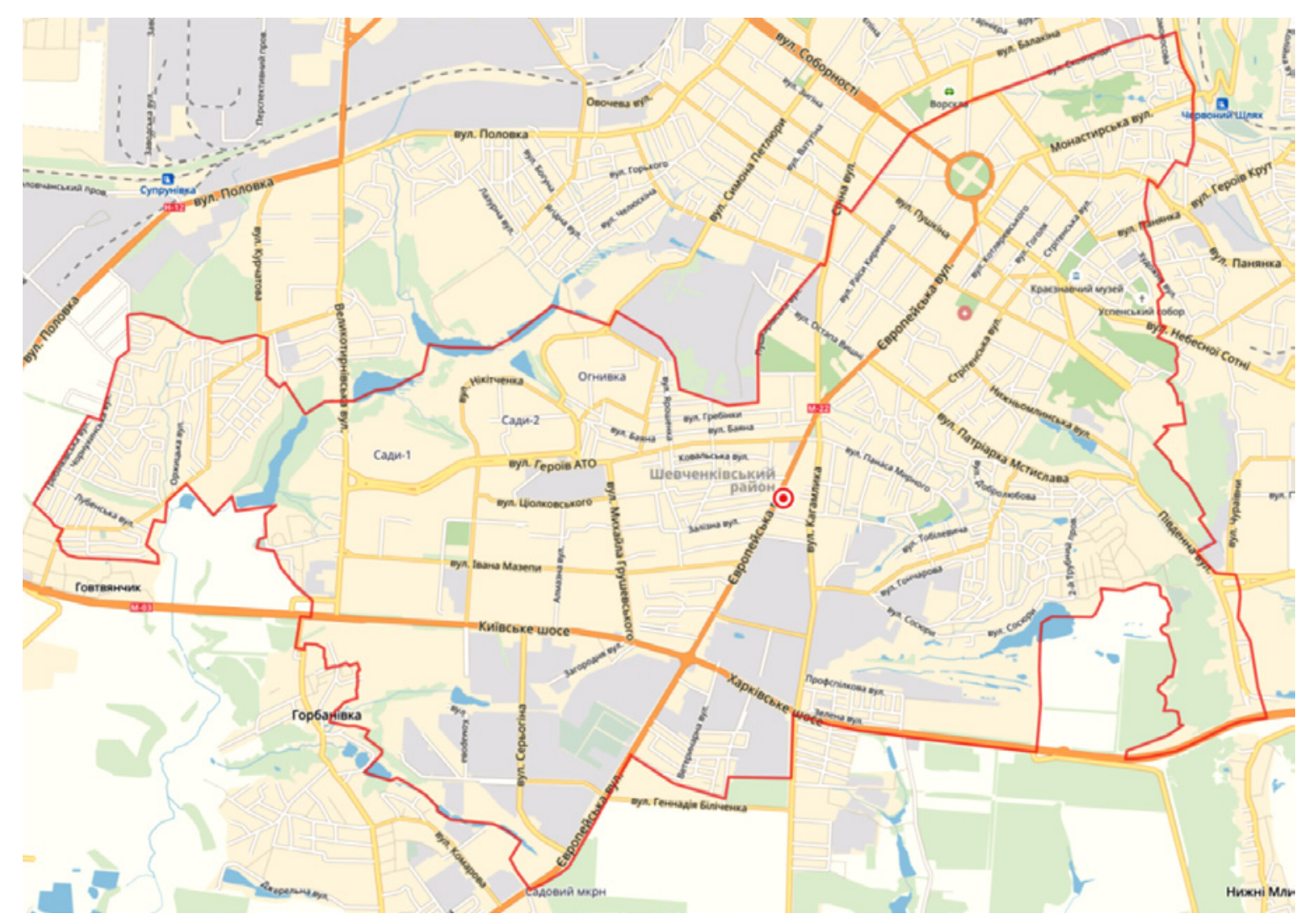

Figure 2. Study area (indicated by a red line) 
infrastructure design in connection with elements of urban design can affect the deterioration of public health or, conversely, hinder aspects of the built environment (Mueller et al., 2015; Sallis et al., 2016; Rojas-Rueda et al., 2016). The negative impact is manifested directly through respiratory diseases and indirectly through climate change (Mueller et al., 2015; Rojas-Rueda et al., 2016). This is justified by the fact that harmful emissions go directly to the surface layers of the atmosphere, where a person is present for a long time, while the conditions for dispersion are the worst (Vitrishchak, 2014). Health effects of primary exhaust gas emissions from engines (e.g. fine particulate matter $\left(\mathrm{PM}_{2.5}\right)$, carbon monoxide $(\mathrm{CO})$, nitrogen oxides $\left(\mathrm{NO}_{\mathrm{X}}\right)$ and sulphur dioxide), $\left(\mathrm{SO}_{2}\right)$ ) and secondary pollutants (such as ozone $\left(\mathrm{O}_{3}\right)$ and $\mathrm{PM}_{2.5}$ are well documented in the medical scientific literature (Attfield et al., 2012; Hesterberg et al., 2012; US EPA, 2002).

Emissions from internal combustion engines account for about $70 \%$ of the most undesirable gases such as carbon oxides $\left(\mathrm{CO}_{\mathrm{X}}\right)$, nitrogen oxides $\left(\mathrm{NO}_{\mathrm{X}}\right)$, sulphur dioxide $\left(\mathrm{SO}_{2}\right)$ and hydrocarbons (Hachem et al., 2021; Hassoon, 2019; CDCP, 2013).

Smog. The word smog is a combination of the words smoke and fog. Mist is a visible aerosol of tiny water droplets or ice crystals suspended in the air; it can be thought of as a low-lying cloud. Due to rapid industrialization and increasing demand for energy and transport around the world, concentrations of volatile organic compounds (of VOCs) and other organic pollutants in the atmosphere are increasing. Thus, smog has become a common environmental problem in many cities in the developing and developed countries of the world (Raza et al., 2021). Smog is a mixture of many pollutants, particulate matter (mainly $\mathrm{PM}_{2.5}$ ) as well as sulphur dioxide $\left(\mathrm{SO}_{\mathrm{X}}\right)$, nitrogen oxides $\left(\mathrm{NO}_{\mathrm{X}}\right)$, carbon monoxide $(\mathrm{CO})$, VOCs, ozone $\left(\mathrm{O}_{3}\right)$ and aldehydes. Each component is harmful to humans, plants, animals and the environment, especially in high concentrations. In recent studies, such effects on humans as general asthma, diabetes, headache, and others have been studied (Butt et al., 2018).

The conditions for the occurrence of smog are a high concentration of dust and gases in the cities' air, the longterm existence of anticyclonic weather conditions, in which pollutants accumulate in the atmosphere's surface layer. Even a short duration of smog (several days) and a high pollutants concentration in the atmosphere contribute to an increase in casualties among the population. The distribution and properties of smog depend on various factors, including wind, temperature, and sunlight (Ali et al., 2019). If smog has existed over a populated area for a very long time, there is a significant increase in the total number of patients due to respiratory diseases (Safi, 2016; Kim et al., 2015). Pollutants, like particulate matter, with high vehicle densities, contribute to situations where the entire city becomes covered with a thick layer of smog, thereby reducing visibility and posing a serious threat to public health (Griffiths, 2016; Yadav \& Rawal, 2016). An example of this is the air quality in New Delhi (India) during November 1-9, 2016. During this period, the situation was so bad due to the increase in both $\mathrm{PM}_{2.5}$ and $\mathrm{PM}_{10}$ levels (Safi, 2016; EWD, 2017).

As a major component of smog, PM in any form is a recognized cause of early mortality. $\mathrm{PM}_{2.5}$ pollutants are the most harmful because such pollutants can penetrate the deep epithelium of the lungs; disrupt the blood-brain barrier and cause coughing, sneezing, shortness of breath and respiratory infections (Yadav \& Rawal, 2016; Grantz et al., 2003) It has been estimated that around two million deaths worldwide are caused by air pollution annually, of which about $25 \%$ are associated with fine PM (Shah et al., 2013). The severity of the smog hazard depends on the amount of air inhaled, the constituents present, and individual characteristics (e.g., weight, age, and well-being) (Raza et al., 2021).

For example, the International Agency for Research on Cancer has classified diesel exhaust as carcinogenic to humans (Group 1) based on sufficient evidence that exposure to diesel exhaust is associated with an increased risk of lung cancer (IARC, 2012). People from the so-called risk group are exposed to the greatest impact: drivers (especially those who work on city buses and taxis) due to prolonged stay in traffic jams, which are usually formed during peak traffic hours (Rouleau et al., 2013; Dirks et al., 2018; Romagnoli et al., 2017). An occupational risk assessment for taxi drivers, traffic police officers, gas station operators and car wash employers has identified a link between high blood CO levels and persistent exposure to vehicle emissions (Yilmaz \& Guvendik, 2003). It is becoming evident that the vapours emitted by the exhaust gases of cars, with their pungent smell of gas or steam, are the cause of a high percentage of accidental poisoning with toxic gases (Rouleau et al., 2013; Cobb \& Etzel, 1991). Consequently, the working conditions of this category of workers require continuous monitoring, similar to research (Kruzhilko et al., 2020).

Carbon monoxide, Nitrogen oxides, sulphur dioxide. Automotive emissions have been found to be responsible for over $97 \%$ of CO in urban centres (Garcia et al., 2013). The slow build-up of this poisonous gas can cause headaches, nausea, vomiting, dizziness and confusion (Mohammed et al., 2019). Carbon monoxide reacts with blood haemoglobin, replacing $\mathrm{O}_{2}$. Because of this, the ability of the blood to oxygenate tissues and organs decreases, hypoxia sets in, therefore, the work of the cardiovascular and nervous systems, as well as muscles, deteriorates (Skoryna \& Nahorna, 2011). The effect of $\mathrm{CO}$ on the central nervous system is manifested in a change in the colour sensitivity of the eyes, which increases 
the likelihood of accidents. CO toxicity increases in the presence of nitrogen in the air.

In the air above highways and adjacent territories, NO and $\mathrm{NO}_{2}$ are most often found with nitrogen oxides. In ambient air, $\mathrm{NO}$ (a colourless gas) is oxidized to $\mathrm{NO}_{2}$ (a stable yellowish-brown gas), which greatly impairs visibility and in most cases imparts a characteristic brown tint to the air). Nitrogen oxides can be especially dangerous in cities, where they interact with carbon in exhaust gases, forming a photochemical fog - smog (Trinh et al., 2017). With an increase in the concentration of $\mathrm{NO}$, severe cough, vomiting, and sometimes headache occur. On contact with the mucous membrane, nitrogen oxides form acids $\mathrm{HNO}_{3}$ and $\mathrm{HNO}_{2}$, which lead to pulmonary edema (at a concentration of 200-300 mg/m $\mathrm{m}^{3}$ ). Nitric dioxide is capable of disrupting the integrity of cell membranes.

Sulphur dioxide even at low concentrations (20-30 mg/ $\mathrm{m}^{3}$ ) creates an unpleasant taste in the mouth, irritates the mucous membranes of the eyes and respiratory tract. At a content of $0.01 \%$, people are poisoned in a few minutes. A mixture of $\mathrm{SO}_{2}$ and $\mathrm{CO}$, with prolonged exposure, causes a violation of the genetic function of the body. Sulphuric acid, formed as a secondary pollutant, also freely penetrates through the mucous membranes of the respiratory tract, causing irritation and inflammation (Skoryna \& Nahorna, 2011).

Interesting are the results of a study where the authors found that exhaust emissions of PM, air toxics, polycyclic aromatic hydrocarbons (PAHs), CO, and total VOCs decreased, while $\mathrm{NO}_{\mathrm{X}}$ emissions increased with the use of biodiesel. Biodiesel use did not impact $\mathrm{NH}_{3}$ and $\mathrm{SO}_{\mathrm{X}}$ emissions (Rouleau et al., 2013).

Ozone, hydrocarbons, and VOCs. It should be noted that ozone is also a pollutant that negatively affects public health. The authors' team (Jia et al., 2011) in their study demonstrates an increase in the risk of mortality by $0.26 \%$ in the case of an increase in the amount of ozone by $10 \mathrm{mg} / \mathrm{m}^{3}$.

Online studies in the urban area of Jinan during MayJuly 2019 and 2020 showed that aromatic hydrocarbons and alkenes were key forms of non-methane hydrocarbons in the formation of $\mathrm{O}_{3}$ (Chai et al., 2021).

Some of PAHs have strong carcinogenic or mutagenic properties (Ravindra et al., 2006) and have therefore been intensively studied over the past decades. The main cause of $90 \%$ of PAHs emissions is the combustion of fossil fuels, industrial processes and domestic heating systems (Ravindra et al., 2006). The predominantly carcinogenic 5,6-ring PAHs are associated with particles, although atmospheric PAHs are distributed between the particles and the gas phase.

Thus, due to the constantly growing number of vehicles and its uneven distribution within the transport network, the overwhelming majority of the urban population lives in areas where the health hazard indices exceed the permissible limits.

Analyzing the existing methods for assessing the anthropogenic load on the atmospheric air, it can be concluded that the main disadvantages include the need for a large amount of initial data, which cannot always be obtained, as well as the need to take into account the contribution of all pollution sources. The methodology, approved in Ukraine (SSR-201-97, 2014), quantitatively characterizes the level of pollution by an individual impurity (pollutant) and allows determining the complex index of atmospheric pollution generated by several substances with summation effects.

Most of the known methods for determining the risk to public health in case of atmospheric air pollution are based on the frequency of exceeding the maximum permissible concentrations of the pollutant. The methodology approved in Ukraine (MR, 2007; OMHU, 2007) allows determining the chronic risk of carcinogenic effects, takes into account the effect of the summation of several pollutants, the safety factor, the values of which vary depending on the hazard class of the substance. In addition, a coefficient can be determined to assess the iso-effective effects of impurities of various hazard classes.

\subsection{Anthropogenic load on the air from vehicle exhaust}

The Air Pollution Index (API) quantitatively characterizes the level of pollution by an individual impurity, taking into account the difference in the rate of growth of the degree of hazardous substances, reduced to the degree of sulphur dioxide hazardousness, with an increase in the excess of $\mathrm{MPC}_{\text {averagedaily. }}$ The pollution index is defined as:

$$
I_{i}=\left(\frac{C_{\text {average }}}{\text { MPC }_{\text {average daily }}^{i}}\right)^{a_{i}}
$$

where $I_{i}$ - unit pollution index for the $i$-th substance; $\mathrm{C}_{\text {average }}$ - the average concentration in the air of the i-th substance; $\mathrm{MPC}_{\text {averagedaily - the maximum allowable }}^{\mathrm{i}}$ average daily concentration for the $\mathrm{i}$-th substance; - dimensionless constant of bringing the degree of harmfulness of the i-th substance to the harmfulness of sulphur dioxide, which depends on the hazard class to which the pollutant belongs.

The results of the distribution of air load from vehicle emissions in the Shevchenko district of Cape Poltava are shown in Figure 3. 


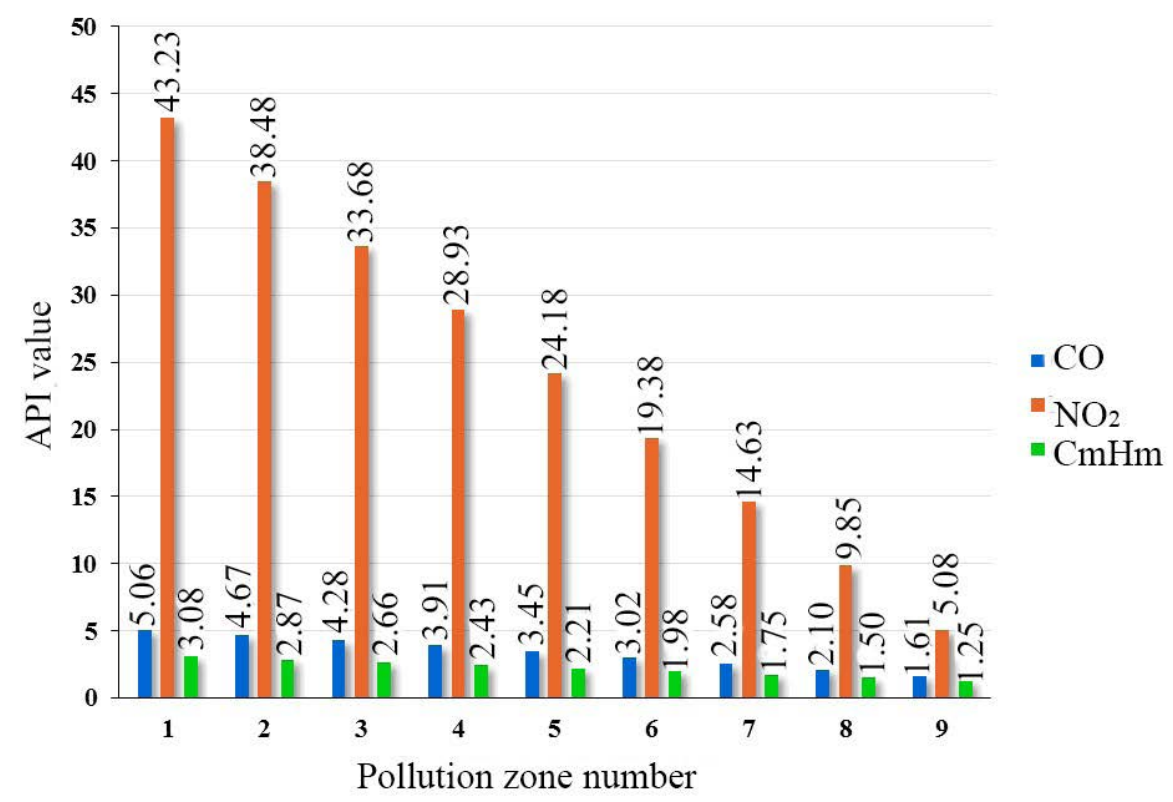

Figure 3. Anthropogenic load from the vehicle exhaust in the Shevchenko district of Poltava

The Integrated Air Pollution Index (IAPI) is a quantitative characteristic of the level of atmospheric air pollution created by several substances present in the atmospheric air:

$\mathrm{I}_{\text {IAPI }}=\sum_{\mathrm{i}=1}^{\mathrm{n}} \mathrm{I}_{\mathrm{i}}=\sum_{\mathrm{i}=1}^{\mathrm{n}}\left(\frac{\mathrm{C}_{\text {average }}}{\text { MPC }_{\text {average daily }}^{\mathrm{i}}}\right)^{\mathrm{a}_{\mathrm{i}}}$

The results of calculating the integrated index of atmospheric air pollution are presented in Table 1.

Table 1. The results of determining the integrated index of atmospheric pollution in the Shevchenko district of Poltava

\begin{tabular}{|c|c|c|c|c|}
\hline $\begin{array}{l}\text { Load } \\
\text { zones }\end{array}$ & $\begin{array}{c}\text { Number of } \\
\text { population, } \\
\text { persons }\end{array}$ & IAPI & Load criterion & $\begin{array}{l}\text { Area part, } \\
\text { percentage }\end{array}$ \\
\hline 1 & 138 & 51.37 & highly polluted atmosphere & \multirow[t]{6}{*}{$54 \%$} \\
\hline 2 & 1342 & 45.97 & highly polluted atmosphere & \\
\hline 3 & 4696 & 40.62 & highly polluted atmosphere & \\
\hline 4 & 14141 & 35.27 & highly polluted atmosphere & \\
\hline 5 & 23909 & 29.84 & highly polluted atmosphere & \\
\hline 6 & 35640 & 24.38 & highly polluted atmosphere & \\
\hline 7 & 34286 & 18.96 & very polluted atmosphere & \multirow[t]{2}{*}{$40 \%$} \\
\hline 8 & 24547 & 13.45 & very polluted atmosphere & \\
\hline 9 & 8970 & 7.94 & polluted atmosphere & $6 \%$ \\
\hline
\end{tabular}

The results show that more than half of the district's population spends most of their time in areas where the complex index of air pollution by test substances is characterized as high, the rest of the population lives in areas with heavily polluted or polluted atmosphere. At risk are mainly children, unemployed youth (schoolchildren), the elderly, who are often on the street and near houses, as well as drivers of vehicles. In turn, such high levels of air pollution pose even greater risks to public health, in particular to the development of respiratory diseases. Therefore, there is a need to create pollutant and risk maps for human health, since even within the one district territory, the hazard indices values can vary significantly (Buchavyy, 2017).

The purpose of ecological mapping is to analyze the ecological situation and its dynamics, i.e. to determine the spatial and temporal variability of environmental factors affecting human health and the ecosystem state (Alexeeff et al., 2018). Air quality maps provide an assessment of environmental justice, research into the sources and dynamics of pollutants, as well as a basis for air quality management and public awareness. They are the basis for the development of comprehensive urban planning measures to protect residential buildings, recreation areas and recreation from pollution.

Maps of scattering of harmful substances are presented in Figs 4-6, maps of risk zones of the population in the Shevchenkivskyi district of Poltava are presented in Figs 7-9. Areas with the same level of risk are indicated by the same colour saturation on the maps, and the zone number is indicated by numbers.

Currently, the most important pollutant of the studied substances is nitrogen dioxide $\left(\mathrm{NO}_{2}\right)$, because its concentrations in some areas exceed $20 \mathrm{MPC}\left(1.73 \mathrm{mg} / \mathrm{m}^{3}\right)$ and this substance is the most influential on the complex rate of pollution. However, due to the ever-increasing number of vehicles, the low level of their greening at present, the slow 


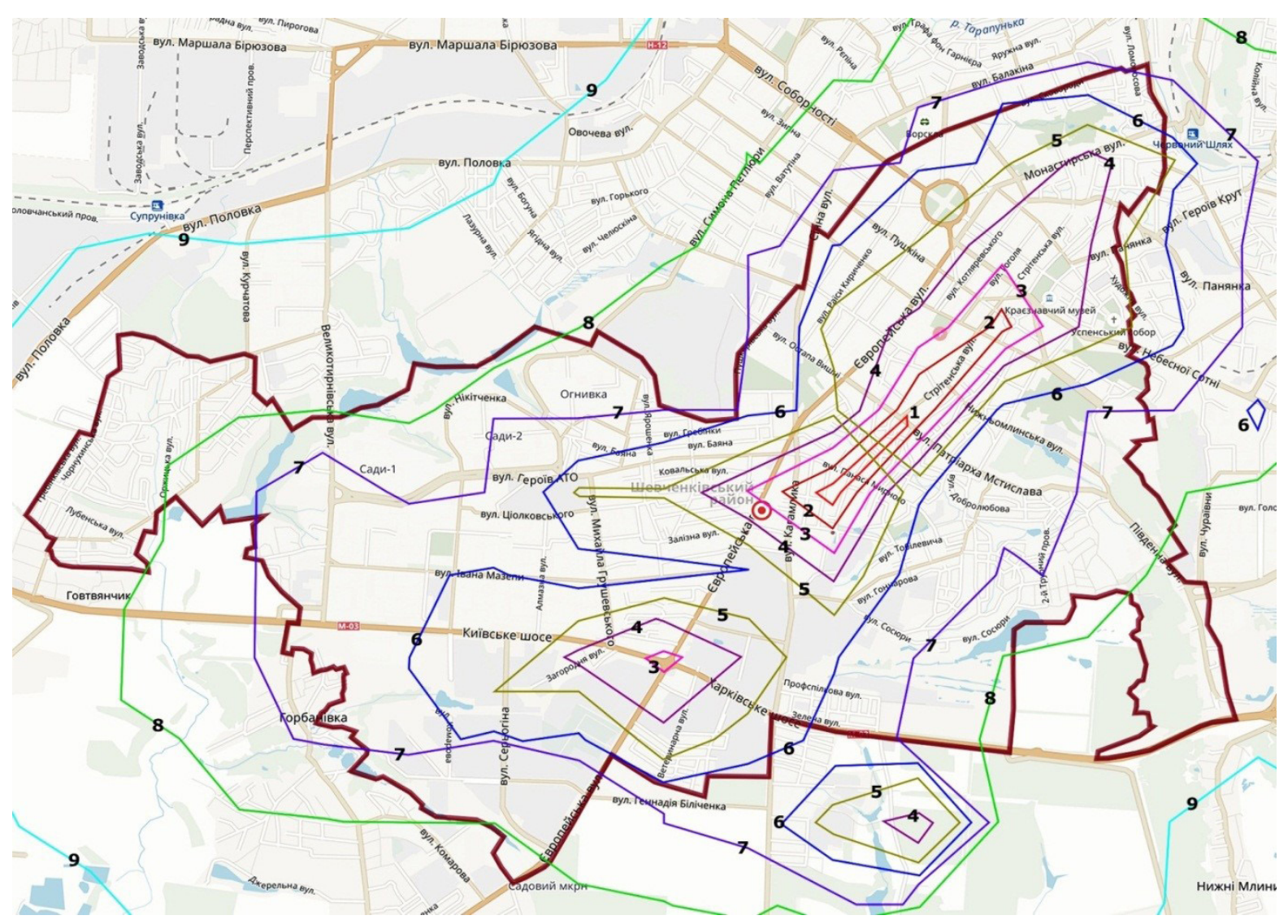

Figure 4. Map of CO scattering: isolines of the same colour and numbers on the maps indicate the same concentrations of pollutants in the fractions of MPC and zone numbers: 1 - 4.55 MPC, 2 - 4.14 MPC, 3 - 3.69 MPC, 4 - 3.25 MPC, 5 - 2, 82 MPC, 6 - 2.39 MPC, 7 - 1.96 MPC, 8 - 1.52 MPC, 9 - 1.09 MPC

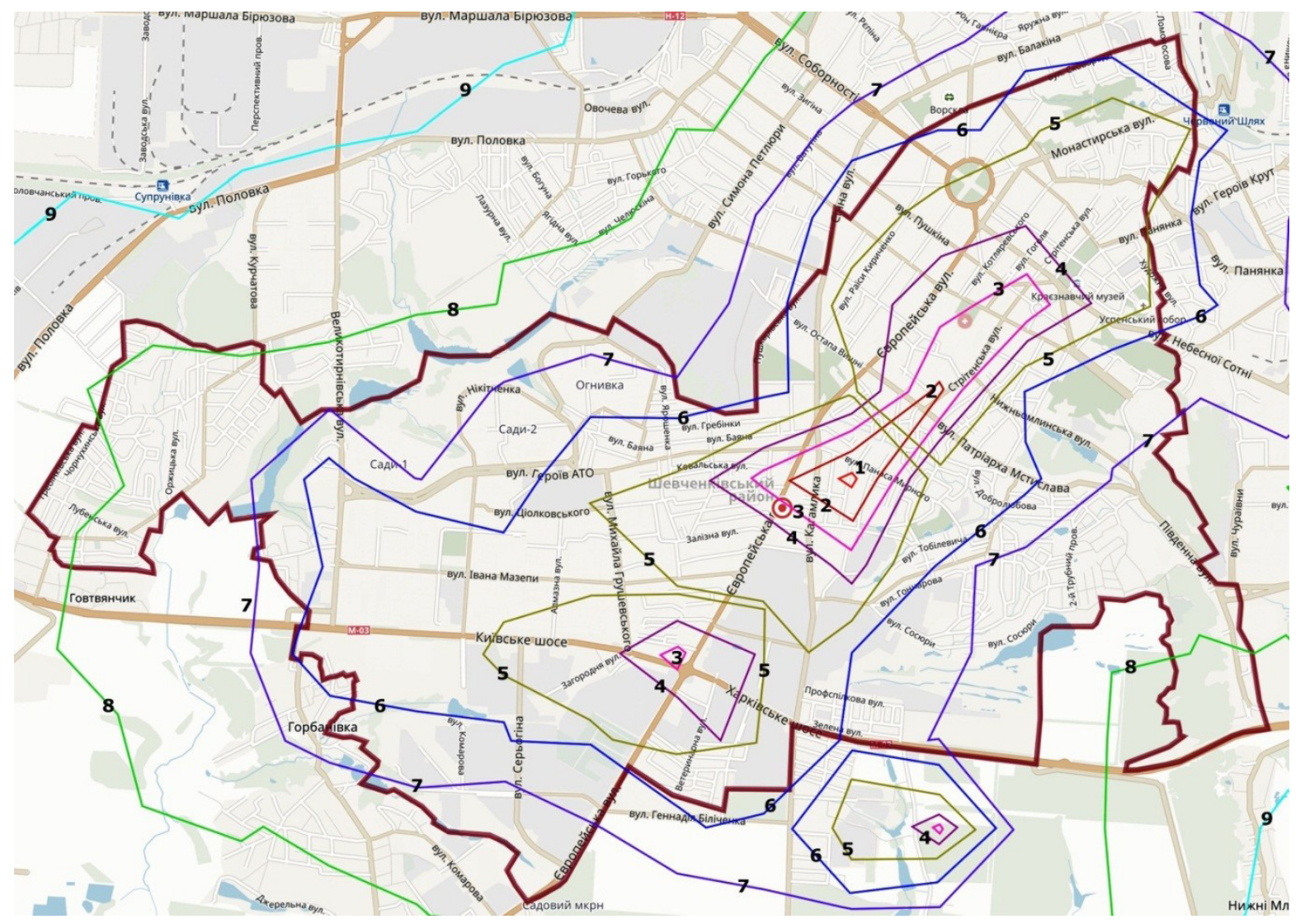

Figure 5. Map of $\mathrm{NO}_{2}$ scattering: isolines of the same colour and numbers on the maps indicate the same concentrations of pollutants in the fractions of MPC and zone numbers: 1 - 20.34 MPC, 2 - 18.10 MPC, 3 - 15.85 MPC, 4 - 13.61 MPC, 5 - 11.37 MPC, 6 - 9.12 MPC, 7 - 6.88 MPC, 8 - 4.63 MPC, 9 - 2.39 MPC 
[80]

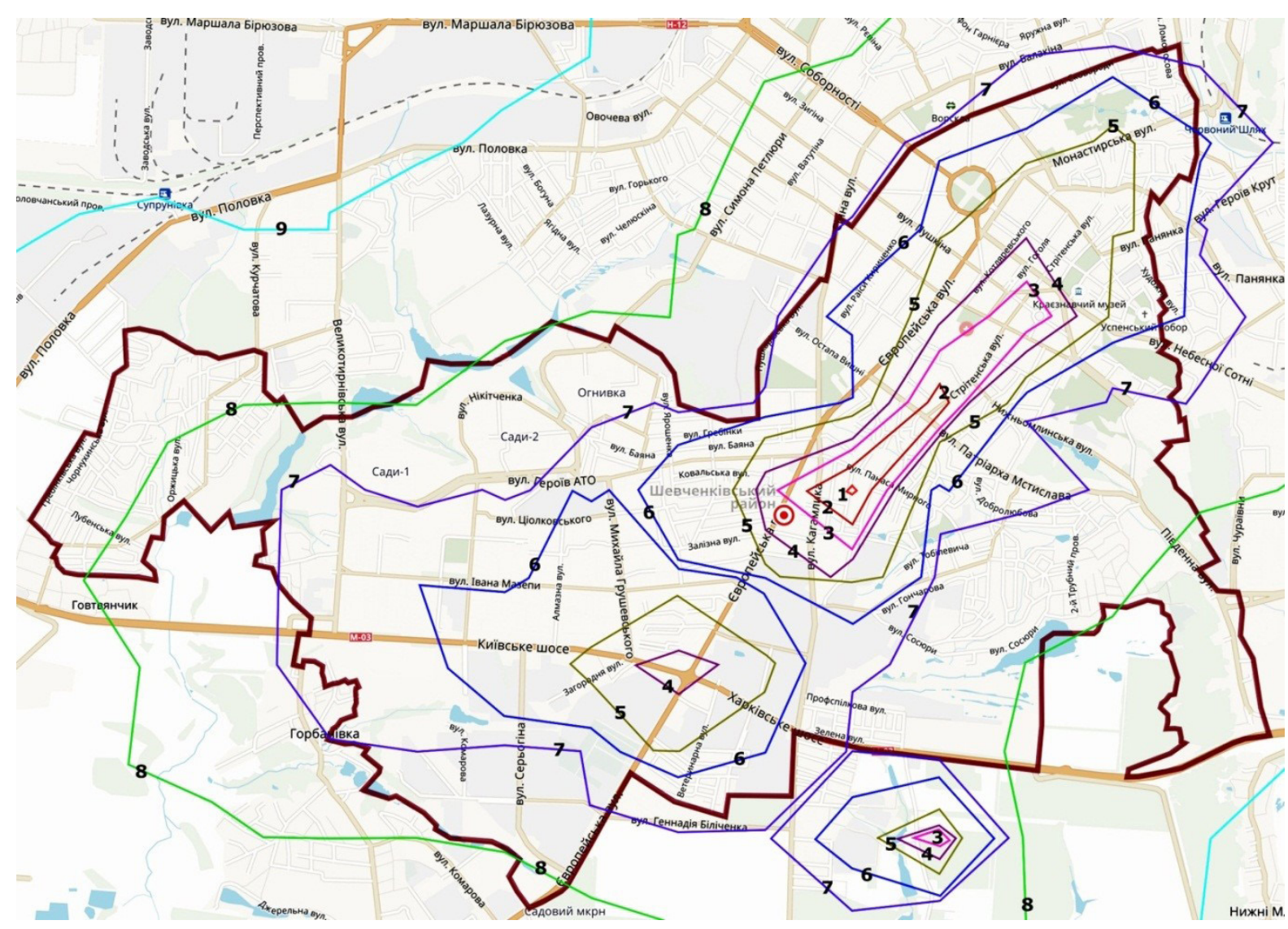

Figure 6. Map of $\mathrm{CmHm}$ scattering: isolines of the same colour and numbers on the maps indicate the same concentrations of pollutants in the fractions of MPC and zone numbers: 1 - 4.08 MPC, 2 - 3.73 MPC, 3 - 3.39 MPC, 4 - 3.04 MPC, 5 - 2.70 MPC, 6 - 2.35 MPC, 7 - 2.01 MPC, 8 - 1.66 MPC, 9 - 1.32 MPC

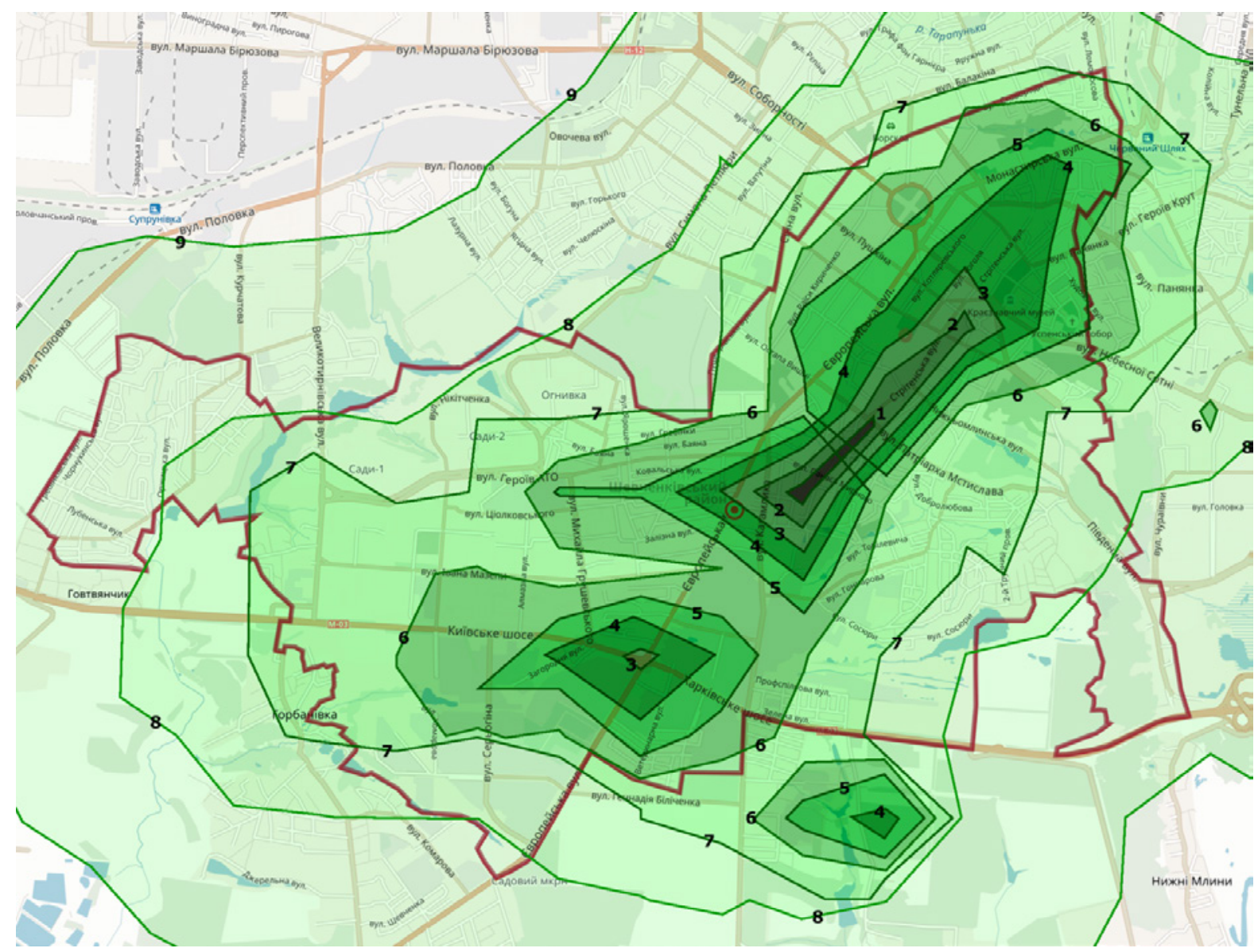

Figure 7. Map of residential risk zones for $\mathrm{CO}$ emissions: areas with the same level of risk are marked with the same colour saturation, and the zone are numbered: $1-0.287,2-0.267,3-0.247,4-0.223,5-0.2,6-0.176,7-0.15,8-0.122,9-0.093$ 


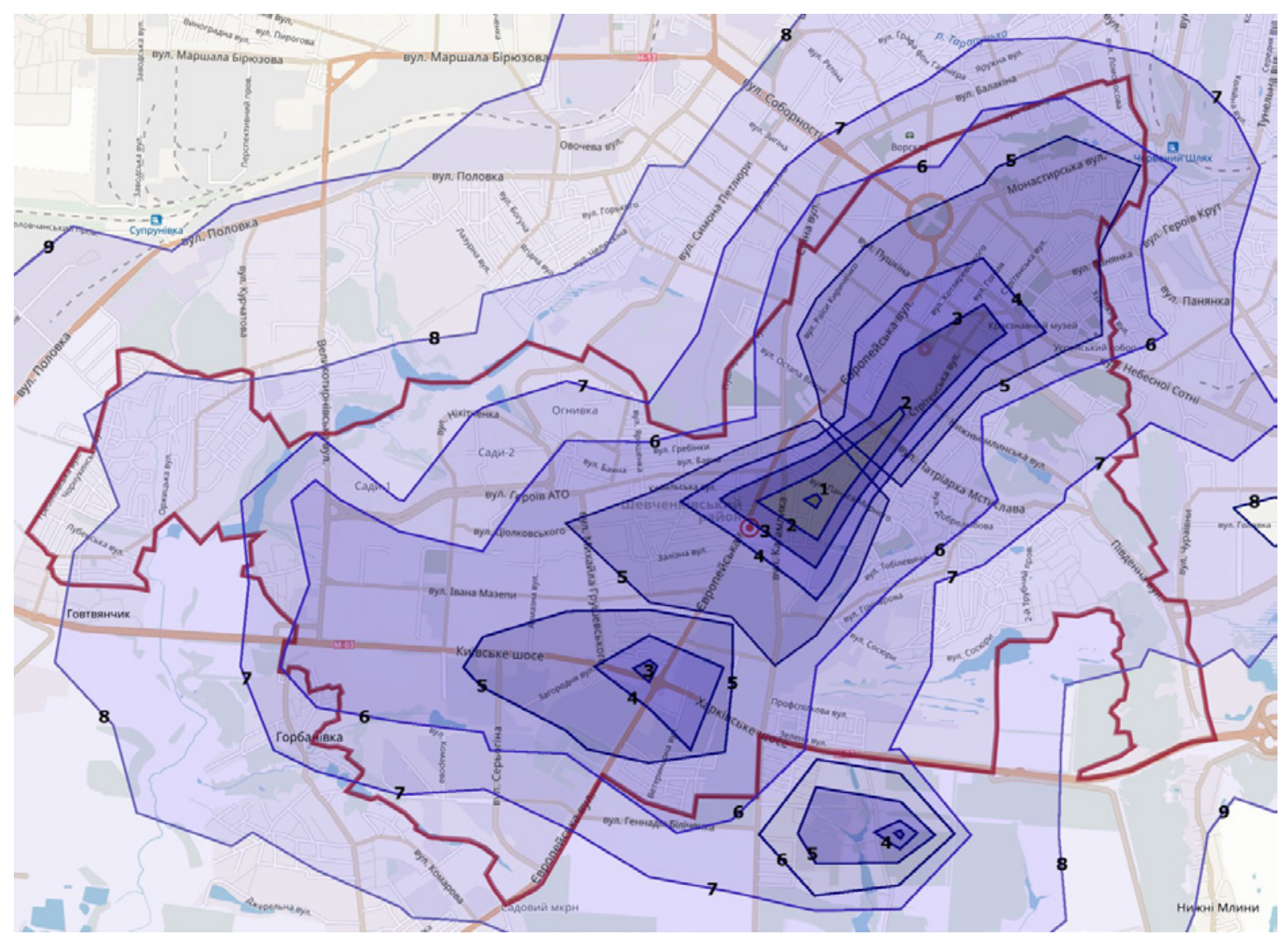

Figure 8. Map of residential risk zones for $\mathrm{NO}_{2}$ emissions: areas with the same level of risk are marked with the same colour saturation, and the zone are numbered: $1-0.812,2-0.775,3-0.729,4-0.674,5-0.608,6-0.528,7-0.432,8-0.317,9-0.179$

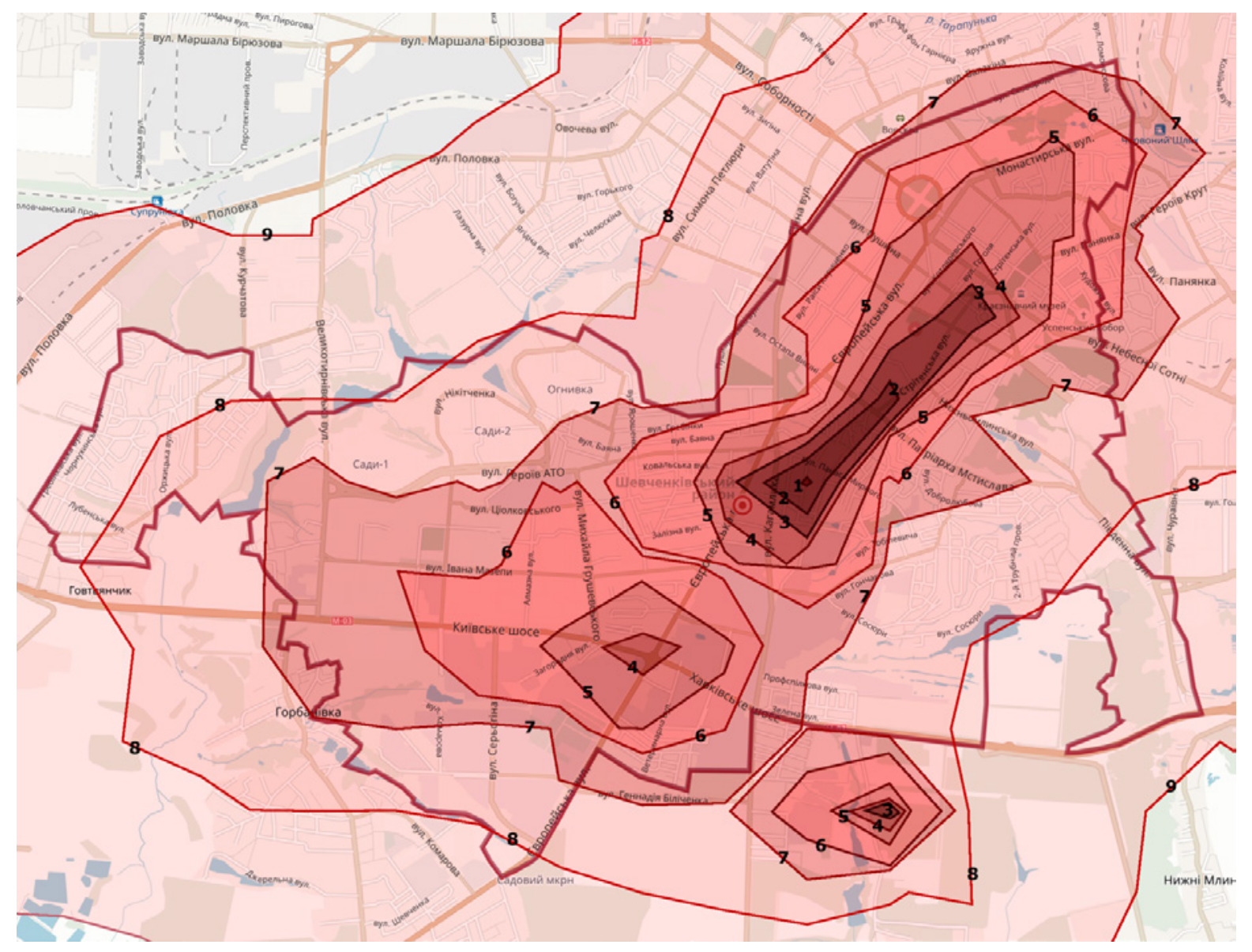

Figure 9. Map of residential risk zones for $\mathrm{CmHm}$ emissions: areas with the same level of risk are marked with the same colour saturation, and the zone are numbered: $1-0.179,2-0.167,3-0.155,4-0.142,5-0.129,6-0.115,7-0.101,8-0.086,9-0.071$ 
pace of introduction of electric vehicles can be expected to increase the pollution level and, consequently, the risk to the population living in the area.

Air pollution maps show increased concentrations of the studied pollutants in the central and north-eastern part of the Shevchenkivskyi district of Poltava. Similar observations are valid for maps of risk zones of the population. This is justified by the presence of many highways of insufficient width for the free movement of cars in a rational speed mode. In addition to this, the pollutants are spread in accordance with the prevailing winds in the northeast direction, which will cover residential and park areas.

It should also be noted that the concentration of pollutants is significantly exceeded at the intersection of Yevropeyska street and Kyyivske Shose street, where there is intense car traffic and "traffic jams" are often observed. Consequently, measures to reduce traffic loads, such as an additional road junction or more rational regulation of traffic lights, are urgently needed.

Unfortunately, the analysis of Ukrainian regulatory documents in the field of environmental safety of the vehicles impact on the environment and public health showed that at present Ukraine has only one officially approved methodology for assessing the risk to public health from air pollution (MR, 2007; OMHU, 2007). At the same time, it should be emphasized that from the point of view of the legislation of developed countries, this technique is very imperfect and needs significant improvement.

In the same time, given the information received, the calculation and assessment of anthropogenic pressures on the atmosphere and public health risks from the effects of road emissions is extremely important. They make it possible to assess the safety of the population and manage the risks associated with the expansion of the road network in order to improve these conditions to safe limits.

It is important that Ukraine has created a mechanism for providing information on the state of the environment. However, the current legislation does not require bringing to the attention of the population information about the concentration specified in paragraph 1 of Art. 7 of Directive 2004/107/EC substances. Therefore, it is necessary to regulate the procedure for bringing information to the refusal of the population, as required by Art. 7 Directive 2004/107/EC.

\subsection{Ways to improve Ukrainian legislation and reduce urban air pollution}

Since in recent years Ukraine has begun an active implementation of pan-European approaches, including ensuring environmental, that is, there is a need to develop an improved methodology for a comprehensive assessment of the risk to public health under the impact of human activity on the environment, adapted to the requirements of European environmental legislation (Living Planet, 2020). For example,

- According to international practice, carcinogenic and non-carcinogenic risks to public health are calculated separately, in contrast to the Ukrainian methodology (OMHU, 2007);

- The hazard factor is calculated separately for the conditions of short-term (acute) and long-term exposure to chemicals (Living Planet, 2020);

The World Health Organization considered $\mathrm{BaP}$ as a sufficient index for PAH carcinogenicity, therefore, the use of $\mathrm{BaP}$-indicator approach in $\mathrm{PAH}$ risks assessment is useful to achieve air quality targets (Kameda et al., 2005; Cheng et al., 2007).

Since $\mathrm{PM}_{2.5}$ emissions are partially related to energy production and consumption (EEA, 2013), European air pollution and climate change mitigation policies require consideration of low-carbon energy scenarios to further reduce emissions from the baseline (Gschwind et al., 2015). All necessary legislative improvements should be added to Ukrainian legislation.

Despite a fairly extensive system of environmental quality standards, the content of $\mathrm{PM}_{2.5}$ and $\mathrm{PM}_{10}$ in the ambient air remains insufficiently regulated. State sanitary rules for the protection of atmospheric air in populated areas (from pollution with chemical and biological substances), approved by order of the Ministry of Health dated July 9, 1997 No. 201 (http://search.ligazakon.ua/1_doc2.nsf/link1/MOZ640.html) regulate only a few types of dust. In Ukraine, there are no methods for separating $\mathrm{PM}_{2.5}$ and $\mathrm{PM}_{10}$ from the total dust mass, and there is no control and monitoring of the content of these substances in the atmospheric air (Anonymous, 2020). At the same time, significant reductions in $\mathrm{PM}_{2.5}$ and other carcinogenic substances concentrations and health effects can be achieved if all technically feasible emission reduction measures are applied (Gschwind et al., 2015).

To achieve the strategic goals for reducing emissions, mobile sources should be:

- established standards for the content of pollutants in accordance with Euro-4 and Euro-5 standards (Anonymous, 2020);

- developed and implemented technological and technical measures to prevent the penetration of pollutants into the environment and their spread in the atmospheric air (Vambol et al., 2016; Vambol et al., 2019; Mozaffari et al., 2021a; Mozaffari et al., 2021b; Mozaffari et al., 2021c; Zeyuan \& Yiguo, 2020).

To reduce $\mathrm{O}_{3}$, the experience of China can be used, where in the urban section of Jinan; two scenarios were developed to stimulate vehicles to refuel at night (Cheng et al., 2007). While this management measure provided a slight relative 
reduction in peak $\mathrm{O}_{3}$ concentrations, it can be applied as an intermediate step towards more efficient interventions.

Since Ukraine is currently not a developed country with a stable economy, then at the current time, the population that is at the greatest risk (area of the most saturated colour, Fig. 7-9) can avoid high pollutants' concentrations in the air, mainly by closing windows and activating air conditioning in air recirculation mode (Hachem et al., 2021). If considered a category of drivers or passengers in a busy traffic flow, then in addition, smooth driving and regular maintenance of the cabin air filters should be ensured (Hachem et al., 2021).

\section{Conclusions}

Most often, to characterize atmospheric air pollution in cities, maps are built on which the main objects affecting the state of the atmosphere, the level of concentrations of pollutants in various regions, the level of complex air pollution on all main highways, in areas of housing and recreation of people, on the territory of industrial enterprises, etc., as well as the characteristics and levels of morbidity of the population.

On the basis of the data of ecological maps, the areas of the city with the greatest load on the atmosphere and the risk to public health are determined. They are the basis for the development of comprehensive urban planning measures to protect residential buildings, recreation and recreation areas from pollution.

The size of the component pollution distributed throughout the city varies within a fairly large range and depends on meteorological conditions, the proximity and number of pollution sources, the number of green spaces, etc.

It should be noted that the creation of maps of pollution and air load allows monitoring of chemical pollution of the environment, studying the patterns of distribution of pollutants in urban areas, and allows over time to adjust design, technical and other solutions to protect the population.

Based on the results obtained, it can be concluded that there is a direct relationship between the amount of air pollution and the risk to public health.

Currently, the most significant pollutant of the studied substances is nitrogen dioxide $\left(\mathrm{NO}_{2}\right)$. In the study area, its concentration may exceed $20 \mathrm{MPC}\left(1.73 \mathrm{mg} / \mathrm{m}^{3}\right)$, and it is this substance that is most floating on the complex indicator of pollution. However, despite the constantly growing number of vehicles, the low level of their greening at the present time, the slow pace of introduction of electric transport into use can be expected to increase the level of pollution and, accordingly, the risk for the population living in this territory.
Taking into account the information received, the calculation and assessment of the anthropogenic load on the atmosphere and health risks of the population from the impact of motor vehicle emissions is extremely important. They allow you to assess the safety of the place of residence of the population and manage the risks associated with the expansion of the road network in order to create a safe living environment.

\section{Acknowledgements}

This study was carried out in accordance with the plans of scientific work of the Department of Applied Ecology and Environmental Sciences, National University "Yuri Kondratyuk Poltava Polytechnic", Poltava, Ukraine. The authors are deeply grateful to the university administration for providing the opportunity for scientific research.

\section{References}

Abdel-Shafy, H. I. \& Mansour M.S., 2016, A review on polycyclic aromatic hydrocarbons: source, environmental impact, effect on human health and remediation. Egyptian Journal of Petroleum 25(1): 107-123.

Alexeeff S.E., Roy A., Shan J., Liu X., Messier K., Apte J.S., Portier C., Sidney S. \& Van Den Eeden S.K., 2018, Highresolution mapping of traffic related air pollution with Google street view cars and incidence of cardiovascular events within neighborhoods in Oakland, CA. Environ. Health 17(1): 38. DOI: 10.1186/s12940-018-0382-1

Ali Y., Razi M., De Felice F., Sabir M. \& Petrillo A., 2019, A VIKOR based approach for assessing the social, environmental and economic effects of "smog" on human health. Sci. Total Environ. 650: 2897-2905.

Anonymous, 2020, Conclusions of the working group on the state of compliance of the legislation of Ukraine in the field of atmospheric air quality with the requirements of EU law in the field of environmental protection. URL: https://www.zhiva-planeta.org.ua/

Attfield M.D., Schleiff P.L., Lubin J.H., Blair A., Stewart P.A., Vermeulen R., Coble J.B. \& Silverman D.T., 2012, The diesel exhaust in miners study: A cohort mortality study with emphasis on lung cancer. J. Natl. Cancer Inst. 104(11): 1-15.

Buchavy Yu.V., 2017, Forecasting of risks to public health from air pollution by emissions of enterprises of the Dnipropetrovsk region. Doctoral Thesis (in Ukrainian). Ministry of Health of Ukraine, P.L. Shupyk National Medical Academy, Kyiv. URL: https://www.nmapo.edu. ua/zagruzka2/DrAr/DrBuchav.pdf 
Butt M., Waseef R. \& Ahmed H., 2018, Perception about the factors associated with smog among medical students. Biomedica 34(4): 264.

CDCP, 2013, Centers for Diseases Control and Prevention Carbon Monoxide hazards from Small Gasoline Gower Engines and Tools. CDCP. NIOSH, pp: 96-118.

Chai W., Shi Y., Hu K., Hou Y., Liang S., Chen W., Wang M. \& Tang G., 2021, Impact of Encouraging Vehicles to Refuel at Night on Ozone and Non-Methane Hydrocarbons (NMHCs): A Case Study in Jinan, China. Atmosphere 12(5): 555. https://doi.org/10.3390/atmos12050555

Cheng J., Yuan T., Wu Q., Zhao W., Xie H., Ma Y., Ma J. \& Wang W., 2007, PM 10-bound polycyclic aromatic hydrocarbons (PAHs) and cancer risk estimation in the atmosphere surrounding an industrial area of Shanghai, China. Water, Air, and Soil Pollution 183(1): 437-446. DOI 10.1007/s11270-007-9392-2

Cobb N. \& Etzel R.A., 1991, Unintentional carbon monoxiderelated deaths in United States, 1979 through 1988. J.A.M.A. 266: 659-663.

Dean J., Wray A., Braun L., et al., 2019, Holding the keys to health? A scoping study of the population health impacts of automated vehicles. BMC Public Health 19: 1258. https://doi.org/10.1186/s12889-019-7580-9

Dirks K.N., Talbot N., Salmond J.A. \& Costello S.B., 2018, In-cabin vehicle carbon monoxide concentrations under different ventilation settings. Atmosphere 9(9): 338.

Dirks K.N., Talbot N., Salmond J.A. \& Costello S.B., 2018, In-cabin vehicle carbon monoxide concentrations under different ventilation settings. Atmosphere 9(9): 338.

EEA, EU-27 air pollution fact sheet. European Environment Agency, 2013, Gschwind B, Lefevre M, Blanc I. Documentation for the Web Service for composite environmental indicator. EnerGEO report; 2012 [October].

EWD, Express Web Desk, 2017, Delhi wakes up to hazardous pollution levels, reduced visibility due to smog. http:// indianexpress.com/article/cities/delhi/delhi- wakes-upto-hazardous-pollution-levels-low-visibility-due-tosmog-3733302/ [Accessed: January 11, 2017].

Garcia L.F.A., Correa S.M., Penteado R., Daemme L.C., Gatti L.V. \& Alvim D.S., 2013, Measurement of emissions from motorcycles and modeling its impact on air quality. J. Braz. Chem. Soc. 24(3): 1-12.

Grantz D., Garner J. \& Johnson D., 2003, Ecological effects of particulate matter. Environ. Int. 29(2-3): 213-239.

Griffiths J., 2016, New Delhi is the most polluted city on Earth right now. http://edition.cnn.com/2016/11/07/asia/ india-new-delhi- smog-pollution/ [Accessed January 11, 2017].

Gschwind B., Lefevre M., Blanc I., Ranchin T., Wyrwa A., Drebszok K., Cofala J. \& Fuss S., 2015, Including the temporal change in PM2. 5 concentration in the assessment of human health impact: Illustration with renewable energy scenarios to 2050. Environmental impact assessment review 52: 62-68. DOI: 10.1016/j. eiar.2014.09.003

Hachem M., Saleh N., Bensefa-Colas L. \& Momas I., 2021, Determinants of ultrafine particles, black carbon, nitrogen dioxide, and carbon monoxide concentrations inside vehicles in the Paris area: PUF-TAXI study. Indoor Air 31(3): 848-859.

Hassoon H.A., 2019, Measurement of carbon monoxide emissions from vehicles exhaust pipe using portable gas detector. Iraqi Journal of Agricultural Sciences 50(3): 936-942.

Hesterberg T.W., Long C.M., Bunn W.B., Lapin C.A., McClellan R.O. \& Valberg P.A., 2012, Health effects research and regulation of diesel exhaust: an historical overview focused on lung cancer risk. Inhal. Toxicol. 24(51): 1-45.

IARC: International Agency for Research on Cancer, 2012, Diesel Engine Exhaust Carcinogenic. World Health Organization, Lyon, France. Press Release No. 213. http:// www.iarc.fr/en/media- centre/pr/2012/pdfs/pr213_E. pdf.

Jia X., Song X., Shima M., Tamura K., Deng F. \& Guo X., 2011, Acute effect of ambient ozone on heart rate variability in healthy elderly subjects. J. Expo. Sci. Environ. Epidemiol. 21(5): 541.

Kameda Y., Shirai J., Komai T., Nakanishi J. \& Masunaga S., 2005, Atmospheric polycyclic aromatic hydrocarbons: size distribution, estimation of their risk and their depositions to the human respiratory tract. Science of The Total Environment 340: 71-80.

Kim K.-H., Kabir E. \& Kabir S., 2015, A Review on the Human Health Impact of Airborne Particulate Matter. Environ Int. 74: 136-143. DOI: 10.1016/j.envint.2014.10.005

Kruzhilko O., Polukarov O., Vambol S., Vambol V., Khan N.A., Maystrenko V., Kalinchyk V.P. \& Khan A.H., 2020, Control of the workplace environment by physical factors and SMART monitoring. Archives of Materials Science and Engineering 103(1): 18-29.

Living Planet, 2020, Living Planet. All-Ukrainian Public Organization for Nature Protection (in Ukrainian). URL: https://www.zhiva-planeta.org.ua/

Martini G., Giechaskiel B. \& Dilara P., 2009, Future European emission standards for vehicles: the importance of the UN-ECE Particle Measurement Programme. Biomarkers 14(sup1.): 29-33. https://doi. org/10.1080/13547500902965393

Mohammed M.N., Ghanesen Y., Al-Zubaidi S., Ali M.A., AlSanjary O.I. \& Zamani N.S., 2019, Investigation on carbon monoxide monitoring and alert system for vehicles. IEEE, 
15th International Colloquium on Signal Processing \& Its Applications (CSPA), pp. 239-242.

Mozaffari N., Mozaffari N., Elahi S.M., Vambol S., Vambol V., Khan N.A. \& Khan N., 2021a, Kinetics study of CO molecules adsorption on $\mathrm{Al} 2 \mathrm{O} 3 /$ Zeolite composite films prepared by roll-coating method. Surface Engineering 37(3): 390-399.

Mozaffari N., Vambol V., Vambol S., Khan A.N. \& Ahmed S., 2021b, Carbon monoxide nanoadsorbent and preparation method there of. Patent of Australia number: 2021100274 from 16.01.2021.

Mozaffari N., Vambol V., Mozaffari N., Vambol S., Khan A.N., Vinod A. \& Mathavan J.J., 2021c, Suspension preparation technique for manufacturing $\mathrm{Al}_{2} \mathrm{O}_{3} / \mathrm{SnO}_{2}$ composite films with adsorption properties. Patent of Australia number: 2021100364 from 20.01.2021.

MR, 2007, On approval of Methodical Recommendations "Assessment of the risk to public health from air pollution". Document v0184282-07, current version - Adoption of 13.04.2007 (in Ukrainian). URL: https://zakon.rada.gov. ua/rada/show/v0184282-07\#Text

Mueller N., Rojas-Rueda D., Cole-Hunter T., de Nazelle A., Dons E., Gerike R., Goetschi T., Panis L.I., Kahlmeier S. \& Nieuwenhuijsen M., 2015, Health impact assessment of active transportation: a systematic review. Prev. Med. 76: 103-14

OMHU, 2007, Order of the Ministry of Health of Ukraine of April 13, 2007 No. 184 on approval of methodological recommendations "Assessment of the risk to public health from air pollution" (in Ukrainian). URL: http://mozdocs. kiev.ua/view.php?id=6902

Ravindra K., Bencs L., Wauters E., Hoog J., Deutsch F., Roekens E., et al., 2006, Seasonal and site-specific variation in vapour and aerosol phase PAHs over Flanders (Belgium) and their relation with anthropogenic activities. Atmospheric Environment 40: 771-785.

Raza W., Saeed S., Saulat H., Gul H., Sarfraz M., Sonne C., Sohn Z.-H., Brown R.J.C. \& Kim K.H., 2021, A review on the deteriorating situation of smog and its preventive measures in Pakistan. Journal of Cleaner Production 279: 123676.

Reşitoğlu İ.A., Altinişik K. \& Keskin A., 2015, The pollutant emissions from diesel-engine vehicles and exhaust aftertreatment systems. Clean Technologies and Environmental Policy 17(1): 15-27. DOI 10.1007/ s10098-014-0793-9

Rojas-Rueda D., De Nazelle A., Andersen Z.J., BraunFahrländer C., Bruha J., Bruhova-Foltynova H., Desqueyroux H., Praznoczy C., Ragettli M.., Tainio M. \& Nieuwenhuijsen M.J., 2016, Health impacts of active transportation in Europe. PLoS One 11(3): e0149990.
Romagnoli P., Balducci, C., Cecinato A., L'Episcopo N., Gariazzo C., Gatto M. P., Gordiani A. \& Gherardi M., 2017, Fine particulate-bound polycyclic aromatic hydrocarbons in vehicles in Rome, Italy. Environmental Science and Pollution Research 24(4): 3493-3505.

Rouleau M., Egyed M., Taylor B., Chen J., Samaali M., Davignon D. \& Morneau G., 2013, Human health impacts of biodiesel use in on-road heavy duty diesel vehicles in Canada. Environmental Science \& Technology 47(22): 13113-13121.

Safi M., 2016, Indian government declares Delhi air pollution an emergency. URL:- https:/www.theguardian.com/ world/2016/nov/06/delhi- air-pollution-closes-schoolsfor-three-days [Accessed: January 11, 2017].

Sallis J.F., Cerin E., Conway T.L., Adams M.A., Frank L.D., Pratt M., Salvo D., Schipperijn J., Smith G., Cain K.L. \& Davey R., 2016, Physical activity in relation to urban environments in 14 cities worldwide: a cross-sectional study. Lancet 387(10034): 2207-2217.

Shah A.S.V., Langrish J.P., Nair H., McAllister D.A., Hunter A.L., Donaldson K., Newby D.E. \& Mills N.L., 2013, Global association of air pollution and heart failure: a systematic review and meta-analysis 382(9897): 1039-1048.

ShDC, 2017, Shevchenkivska District Council in Poltava (in Ukrainian). URL: http://okt-rada.gov.ua/ [Accessed: January 11, 2017].

Singh S.G., 2020, Air pollution: health effects. Med. Leg. Costa Rica 37(1): 33-38.

Skoryna L.M. \& Nagorna A.V., 2011, Influence of motor vehicle emissions on the development of agricultural organizations in the Vinnytsia region. Bulletin of Vinnytsia Polytechnic Institute 6: 20-23 (in Ukrainian).

SSR-201-97, 2014, State sanitary rules for protection of atmospheric air of settlements (from pollution by chemical and biological substances). Document v0201282-97 (in Ukrainian). URL: https://zakon.rada. gov.ua/rada/show/v0201282-97\#Text

SSSU, 2018, State Statistics Service of Ukraine. The current population of Ukraine (in Ukrainian). URL: http:// database.ukrcensus.gov.ua/PXWEB2007/ukr/publ_ new1/2018/zb_chnn2018.pdf

Topacoglu H., Katsakoglou S. \& Ipekci A., 2014, Effect of exhaust emissions on carbon monoxide levels in employees working at indoor car wash facilities. Quarterly Medical Journal 18(1): 37-39.

Trinh H.T., Imanishi K., Morikawa T., Hagino H. \& Takenaka N., 2017, Gaseous nitrous acid (HONO) and nitrogen oxides (NOx) emission from gasoline and diesel vehicles under real-world driving test cycles. Journal of the Air \& Waste Management Association 67(4): 412-420.

Uhrner U., Von Löwis S., Vehkamäki H., Wehner B., Bräsel S., Hermann M. \& Wiedensohler A., 2007, Dilution and 
aerosol dynamics within a diesel car exhaust plumeCFD simulations of on-road measurement conditions. Atmospheric Environment 41(35): 7440-7461.

US EPA, 2002, Health Assessment Document for Diesel Engine Exhaust. National Center for Environmental Assessment for the Once of Transportation and Air Quality, US EPA, Washington, D.C. EPA/600/8-90/ 057F. Vambol S.A., Shakhov Yu.V., Vambol V.V. \& Petukhov I.I., 2016, A mathematical description of the separation of gas mixtures generated by the thermal utilization of waste. Eastern-European Journal of Enterprise Technologies 1/2(79): 35-41. DOI: 10.15587/1729-4061.2016.60486

Vambol S., Vambol V. \& Al-Khalidy K.A.H., 2019, Experimental study of the effectiveness of water-air suspension to prevent an explosion. Journal of Physics: Conference Series 1294(7): 072009. https://iopscience. iop.org/issue/1742-6596/1294/7
Vitryshchak S.V., 2014, Atmospheric air pollution by motor vehicle emissions is a real danger for the nation. Young Scientist 3 (6): 125-126 (in Ukrainian).

Yadav S. \& Rawal G., 2016, The great Delhi smog. Indian Journal of Immunology and Respiratory Medicine 1(4): 78-79.

YilmazA.\&GuvendikG.,2003, The blood carboxyhemoglobin levels of individuals occupationally exposed to exhaust pollution. J. Fac. Pharm., Ankara 32: 213-219.

Zeyuan Z. \& Yiguo H., 2020, Fuel cell passenger car air filter system with silencing function Patent of China number: CN211819865 (U) from 30.10.2020.

Ziarati P., Vambol V. \& Vambol S., 2020, Use of inductively coupled plasma optical emission spectrometry detection in determination of arsenic bioaccumulation in Trifolium pratense L. from contaminated soil. Ecological Questions 31(1): 15-22. DOI: 10.12775/EQ.2020.003

\section{Annex A}

Characteristics of motor traffic flow and volumetric emission of pollutants in Shevchenkivskyi district of Poltava

\begin{tabular}{|c|c|c|c|c|c|}
\hline $\begin{array}{c}\text { No. the } \\
\text { investigated } \\
\text { section of } \\
\text { the highway }\end{array}$ & $\begin{array}{l}\text { Name of the street (and number of buildings) on } \\
\text { which the section of the highway falls }\end{array}$ & $\begin{array}{l}\text { Hourly traffic } \\
\text { intensity on the } \\
\text { road section, } \\
\text { car/hour, }\end{array}$ & CO emission, $\mathrm{g} / \mathrm{s}$ & $\begin{array}{l}\mathrm{NO}_{2} \text { emission, } \\
\mathrm{g} / \mathrm{s}\end{array}$ & $\begin{array}{l}\text { CmHm emis- } \\
\text { sion, g/s }\end{array}$ \\
\hline 1 & 2 & 3 & 4 & 5 & 6 \\
\hline 1. & Sobornosti (39-43) & 1405 & 8.277 & 0.553 & 1.380 \\
\hline 2. & Sobornosti (42) & 658 & 1.505 & 0.101 & 0.251 \\
\hline 3. & Teatralna (42-1v) & 270 & 1.446 & 0.096 & 0.241 \\
\hline 4. & Sobornosti (40) & 596 & 1.152 & 0.077 & 0.192 \\
\hline 5. & Vyacheslava Chornovola $(2,2 \mathrm{a}, 2 \mathrm{~b}, 5)$ & 150 & 0.950 & 0.063 & 0.158 \\
\hline 6. & Sobornosti (38) & 583 & 1.017 & 0.068 & 0.170 \\
\hline 7. & Sobornosti (36) & 690 & 1.752 & 0.118 & 0.292 \\
\hline 8. & Sobornosti (31) & 702 & 1.403 & 0.094 & 0.234 \\
\hline 9. & Sobornosti (33) & 1023 & 2.277 & 0.152 & 0.380 \\
\hline 10. & Sobornosti (35) & 967 & 2.162 & 0.144 & 0.360 \\
\hline 11. & Sobornosti (37) & 962 & 1.898 & 0.127 & 0.316 \\
\hline 12. & 1100 roku Poltavy $(2-4)$ & 859 & 2.374 & 0.159 & 0.396 \\
\hline 13. & Monastyrska (10-59) & 474 & 10.158 & 0.687 & 1.697 \\
\hline 14. & Volodymyra Kozaka (2-18) & 595 & 4.849 & 0.326 & 0.809 \\
\hline 15. & Maydan Nezalezhnosti (5, 5a, 3, 3a, 1a, 8, 1, 1a, 1b, 1v) & 465 & 3.511 & 0.237 & 0.587 \\
\hline 16. & Yevropeyska (1-21) & 170 & 1.202 & 0.080 & 0.200 \\
\hline 17. & Sholom - Aleykhema (2-45) & 715 & 7.844 & 0.528 & 1.309 \\
\hline 18. & Dmytra Koryaka (2-43) & 468 & 2.758 & 0.184 & 0.460 \\
\hline 19. & Pushkina (13-79) & 561 & 2.310 & 0.154 & 0.385 \\
\hline 20. & Pushkina (42-63) & 482 & 3.457 & 0.233 & 0.577 \\
\hline 21. & Pushkina (24-45) & 427 & 2.334 & 0.156 & 0.389 \\
\hline 22. & Haharina $(1,3,5,10,14)$ & 365 & 2.000 & 0.134 & 0.334 \\
\hline
\end{tabular}




\begin{tabular}{|c|c|c|c|c|c|}
\hline $\begin{array}{c}\text { No. the } \\
\text { investigated } \\
\text { section of } \\
\text { the highway }\end{array}$ & $\begin{array}{c}\text { Name of the street (and number of buildings) on } \\
\text { which the section of the highway falls }\end{array}$ & $\begin{array}{c}\text { Hourly traffic } \\
\text { intensity on the } \\
\text { road section, } \\
\text { car/hour, }\end{array}$ & CO emission, $\mathrm{g} / \mathrm{s}$ & $\begin{array}{l}\mathrm{NO}_{2} \text { emission, } \\
\mathrm{g} / \mathrm{s}\end{array}$ & $\begin{array}{l}\text { CmHm emis- } \\
\text { sion, } \mathrm{g} / \mathrm{s}\end{array}$ \\
\hline 1 & 2 & 3 & 4 & 5 & 6 \\
\hline 23. & Yevropeyska $(6,8,10)$ & 890 & 3.339 & 0.224 & 0.557 \\
\hline 24. & Yevropeyska (18-47) & 1062 & 11.630 & 0.775 & 1.938 \\
\hline 25. & Yevropeyska & 1542 & 21.768 & 1.451 & 3.628 \\
\hline 26. & Patriarkha Mstyslava (4-31) & 648 & 3.556 & 0.237 & 0.593 \\
\hline 27. & Patriarkha Mstyslava (31-79) & 368 & 3.976 & 0.268 & 0.664 \\
\hline 28. & Stritenska (52-63) & 210 & 1.493 & 0.100 & 0.249 \\
\hline 29. & Stritenska $(50,59,57,55,53,51 \mathrm{a}, 49,47 \mathrm{a}, 47 \mathrm{~b})$ & 199 & 1.408 & 0.094 & 0.235 \\
\hline 30. & May Day Avenue (5-13) & 167 & 1.043 & 0.070 & 0.174 \\
\hline 31. & Nebesnoyi Sotni (21-44) & 1129 & 13.128 & 0.877 & 2.189 \\
\hline 32. & Nebesnoyi Sotni (3-13) & 1094 & 14.281 & 0.956 & 2.382 \\
\hline 33. & Nyzhnomlynska (1-23) & 390 & 3.299 & 0.220 & 0.550 \\
\hline 34. & Panyanka (1-5) & 375 & 1.938 & 0.130 & 0.323 \\
\hline 35. & Pylypa Orlyka (1-36) & 108 & 0.471 & 0.031 & 0.079 \\
\hline 36. & Hoholya (26-35) & 161 & 0.628 & 0.042 & 0.105 \\
\hline 37. & Monastyrska (5a-7) & 408 & 1.173 & 0.079 & 0.196 \\
\hline 38. & Volodymyra Kozaka $(1 \mathrm{a}, 8,10)$ & 558 & 1.452 & 0.097 & 0.242 \\
\hline 39. & Luhova (1-39) & 331 & 2.623 & 0.175 & 0.437 \\
\hline 40. & Shevchenka (31-54) & 412 & 1.976 & 0.134 & 0.330 \\
\hline 41. & Shevchenka (22-36) & 337 & 1.586 & 0.106 & 0.264 \\
\hline 42. & Shevchenka (4-18) & 158 & 1.302 & 0.087 & 0.217 \\
\hline 43. & M. Hrushevskoho (1-4) & 318 & 2.265 & 0.151 & 0.377 \\
\hline 44. & M. Hrushevskoho (4-22) & 627 & 7.335 & 0.495 & 1.225 \\
\hline 45. & Tsiolkovskoho (1-21) & 325 & 2.242 & 0.149 & 0.374 \\
\hline 46. & Tsiolkovskoho (21-37) & 306 & 1.706 & 0.114 & 0.284 \\
\hline 47. & Almazna $(1,2,3,6)$ & 117 & 0.685 & 0.046 & 0.114 \\
\hline 48. & Almazna (5-18) & 119 & 0.715 & 0.048 & 0.119 \\
\hline 49. & Stepovoho Frontu (1-48) & 629 & 3.665 & 0.365 & 0.659 \\
\hline 50. & Ivana Mazepy (1-13) & 1107 & 7.309 & 0.491 & 1.219 \\
\hline 51. & Ivana Mazepy (13-37) & 713 & 6.323 & 0.422 & 1.054 \\
\hline 52. & Ivana Mazepy (37-59) & 813 & 9.614 & 0.641 & 1.602 \\
\hline 53. & 23 Veresnya $(1-7)$ & 714 & 4.527 & 0.311 & 0.758 \\
\hline 54. & 23 Veresnya $(8-23)$ & 1128 & 11.185 & 0.746 & 1.864 \\
\hline 55. & Kyyivske Road (4-38) & 921 & 5.012 & 0.396 & 0.860 \\
\hline 56. & Kyyivske Road (44-48) & 941 & 7.825 & 0.621 & 1.344 \\
\hline 57. & Kyyivske Road (50-60) & 756 & 7.074 & 0.545 & 1.208 \\
\hline 58. & Kyyivske Road (62-92) & 1062 & 13.819 & 0.928 & 2.306 \\
\hline 59. & Velykotyrnivska (1-10) & 917 & 5.544 & 0.397 & 0.935 \\
\hline 60. & Velykotyrnivska (10-22) & 849 & 4.940 & 0.344 & 0.829 \\
\hline 61. & Heroes of the anti-terrorist operation (71-83) & 984 & 13.023 & 0.873 & 2.172 \\
\hline 62. & Heroyiv Stalinhradu (1-9) & 706 & 4.900 & 0.328 & 0.817 \\
\hline 63. & Heroyiv Stalinhradu (9-17) & 820 & 5.958 & 0.397 & 0.993 \\
\hline 64. & Pivdenna $(1 \mathrm{a}-7)$ & 385 & 0.624 & 0.042 & 0.104 \\
\hline 65. & Pivdenna (11-75) & 879 & 10.585 & 0.710 & 1.766 \\
\hline 66. & Pivdenna (77-159) & 38 & 0.571 & 0.038 & 0.095 \\
\hline \multirow{2}{*}{$\begin{array}{l}67 . \\
68 .\end{array}$} & Mykoly Vavylova Avenue adjacent to Churayivny Street, & 897 & 1.93 & 0.129 & 0.322 \\
\hline & which passes near the gas station & 527 & 1.312 & 0.089 & 0.219 \\
\hline 69. & Chovnovyy bystreet (24-30) & 20 & 0.058 & 0.004 & 0.010 \\
\hline 70. & Dzherelnyy bystreet (7-15) & 11 & 0.030 & 0.002 & 0.005 \\
\hline
\end{tabular}




\begin{tabular}{|c|c|c|c|c|c|}
\hline $\begin{array}{c}\text { No. the } \\
\text { investigated } \\
\text { section of } \\
\text { the highway }\end{array}$ & $\begin{array}{l}\text { Name of the street (and number of buildings) on } \\
\text { which the section of the highway falls }\end{array}$ & $\begin{array}{l}\text { Hourly traffic } \\
\text { intensity on the } \\
\text { road section, } \\
\text { car/hour, }\end{array}$ & CO emission, $\mathrm{g} / \mathrm{s}$ & $\begin{array}{l}\mathrm{NO}_{2} \text { emission, } \\
\mathrm{g} / \mathrm{s}\end{array}$ & $\begin{array}{l}\text { CmHm emis- } \\
\text { sion, } g / s\end{array}$ \\
\hline 1 & 2 & 3 & 4 & 5 & 6 \\
\hline 71. & Patriarkha Mstyslava (68-70) & 401 & 0.482 & 0.032 & 0.080 \\
\hline 72. & Patriarkha Mstyslava (72-134) & 474 & 6.460 & 0.435 & 1.079 \\
\hline 73. & Dovzhenka (107-115) & 73 & 0.256 & 0.018 & 0.043 \\
\hline 74. & Dovzhenka (70-103) & 65 & 0.196 & 0.013 & 0.033 \\
\hline 75. & Dovzhenka (55-68) & 58 & 0.370 & 0.025 & 0.062 \\
\hline 76. & Dovzhenka (28-53) & 30 & 0.094 & 0.006 & 0.016 \\
\hline 77. & Dovzhenka (2-35) & 24 & 0.083 & 0.006 & 0.014 \\
\hline 78. & Hlybokyy bystreet (3-16) & 18 & 0.050 & 0.003 & 0.008 \\
\hline 79. & Hlybokyy bystreet (22-50) & 15 & 0.072 & 0.005 & 0.012 \\
\hline 80. & Hlybokyy bystreet (54-72) & 17 & 0.096 & 0.006 & 0.016 \\
\hline 81. & Tobilevycha (3-25/5) & 19 & 0.085 & 0.006 & 0.014 \\
\hline 82. & Sofiyi Kovalevskoyi (1-29) & 35 & 0.153 & 0.010 & 0.026 \\
\hline 83. & Sofiyi Kovalevskoyi (29a-63) & 13 & 0.079 & 0.005 & 0.013 \\
\hline 84. & Verkhniy bystreet (22/1-28) & 27 & 0.072 & 0.005 & 0.012 \\
\hline 85. & Verkhniy bystreet (3-16/2) & 23 & 0.070 & 0.005 & 0.012 \\
\hline 86. & Malorudchanska (1-23) & 64 & 0.278 & 0.020 & 0.047 \\
\hline 87. & Veterynarna (17b-26) & 29 & 0.171 & 0.011 & 0.029 \\
\hline 88. & Veterynarna (28a-32) & 24 & 0.069 & 0.005 & 0.011 \\
\hline 89. & Danyla Apostola (4-7b) & 31 & 0.126 & 0.008 & 0.021 \\
\hline 90. & Danyla Apostola (9a-27) & 24 & 0.108 & 0.007 & 0.018 \\
\hline 91. & Oresta Levytskoho (1-4) & 84 & 0.419 & 0.028 & 0.070 \\
\hline 92. & Oresta Levytskoho (10-40) & 36 & 0.242 & 0.017 & 0.041 \\
\hline 93. & Kharkivske Road (4/15) & 1025 & 6.886 & 0.526 & 1.174 \\
\hline 94. & Kharkivske Road (8) & 1230 & 6.239 & 0.501 & 1.074 \\
\hline 95. & Kahamlyka (2/43-53) & 892 & 2.178 & 0.159 & 0.368 \\
\hline 96. & Serafymovycha $(2 / 43-22 / 1)$ & 14 & 0.046 & 0.003 & 0.008 \\
\hline 97. & Profspilkova (2/39-49) & 35 & 0.184 & 0.012 & 0.031 \\
\hline 98. & Kharkivske Road (6-29) & 1067 & 11.710 & 0.926 & 2.010 \\
\hline 99. & Sinna (29) - Shevchenka (63a) & 1597 & 6.917 & 0.537 & 1.183 \\
\hline 100. & Shevchenka (63a-59) & 747 & 3.394 & 0.274 & 0.585 \\
\hline 101. & Pushkina (93-83/91) & 1317 & 1.649 & 0.156 & 0.293 \\
\hline 102. & Sinna $(29-31 / 32)$ & 1565 & 3.012 & 0.235 & 0.516 \\
\hline 103. & Heroyiv Chornobyltsiv (30a-30) & 600 & 1.074 & 0.090 & 0.186 \\
\hline 104. & Heroyiv Chornobyltsiv (30) - Tupyy bystreet (2) & 49 & 0.280 & 0.020 & 0.047 \\
\hline 105. & Heroyiv Chornobyltsiv (28) - Rayisy Kyrychenko & 260 & 0.656 & 0.046 & 0.110 \\
\hline 106. & Rayisy Kyrychenko (43) - Shevchenka (43) & 97 & 0.250 & 0.017 & 0.042 \\
\hline 107. & Heroyiv Chornobyltsiv (19) - Rayisy Kyrychenka (67) & 103 & 0.736 & 0.053 & 0.124 \\
\hline 108. & Heroyiv Chornobyltsiv (14) - Novyy bazar (22) & 977 & 2.643 & 0.209 & 0.454 \\
\hline 109. & Novyy bazar (22-4) & 943 & 5.132 & 0.369 & 0.866 \\
\hline 110. & Heroyiv Chornobyltsiv (9b-5) & 721 & 1.309 & 0.103 & 0.225 \\
\hline 111. & Chornovola (25/7-43) & 569 & 3.908 & 0.276 & 0.658 \\
\hline 112. & Novyy bazar (15/4-31) & 701 & 3.679 & 0.274 & 0.625 \\
\hline 113. & Heroyiv Chornobyltsiv (5-2) & 687 & 1.663 & 0.130 & 0.285 \\
\hline 114. & Heroyiv Chornobyltsiv (30a) - Sinna (43) & 1524 & 11.940 & 0.961 & 2.056 \\
\hline 115. & Olesya Honchara (1b-24) & 533 & 0.940 & 0.081 & 0.164 \\
\hline 116. & Ostapa Vyshni (14a) - Vsihsvatskij bystreet (5) & 129 & 0.673 & 0.048 & 0.113 \\
\hline 117. & Rayisy Kyrychenko (72-66) & 1422 & 5.064 & 0.419 & 0.877 \\
\hline
\end{tabular}




\begin{tabular}{|c|c|c|c|c|c|}
\hline $\begin{array}{c}\text { No. the } \\
\text { investigated } \\
\text { section of } \\
\text { the highway }\end{array}$ & $\begin{array}{l}\text { Name of the street (and number of buildings) on } \\
\text { which the section of the highway falls }\end{array}$ & $\begin{array}{l}\text { Hourly traffic } \\
\text { intensity on the } \\
\text { road section, } \\
\text { car/hour, }\end{array}$ & CO emission, $\mathrm{g} / \mathrm{s}$ & $\begin{array}{l}\mathrm{NO}_{2} \text { emission, } \\
\mathrm{g} / \mathrm{s}\end{array}$ & $\begin{array}{l}\text { CmHm emis- } \\
\text { sion, } \mathrm{g} / \mathrm{s}\end{array}$ \\
\hline 1 & 2 & 3 & 4 & 5 & 6 \\
\hline 118. & Rayisy Kyrychenko (66) - Yevropeyska (66) & 1478 & 2.513 & 0.189 & 0.427 \\
\hline 119. & Bayana (1a-56) & 643 & 7.269 & 0.627 & 1.268 \\
\hline 120. & Bayana (56-53) & 643 & 3.032 & 0.257 & 0.527 \\
\hline 121. & Hrebinky (28-80a) & 139 & 0.949 & 0.071 & 0.161 \\
\hline 122. & Hrebinky (80a-95) & 122 & 0.570 & 0.042 & 0.097 \\
\hline 123. & Rayisy Kyrychenko (66-84) & 1341 & 7.360 & 0.652 & 1.291 \\
\hline 124. & Panasa Myrnoho (3-40) & 28 & 0.271 & 0.018 & 0.045 \\
\hline 125. & Kahamlyka (3-29) & 527 & 4.379 & 0.318 & 0.740 \\
\hline 126. & Lesi Ukrayinky (3-23) & 22 & 0.234 & 0.016 & 0.039 \\
\hline 127. & Olenky Pchilky (19-2) & 14 & 0.097 & 0.006 & 0.016 \\
\hline 128. & Chaykovskoho bystreet (1-4) & 65 & 0.254 & 0.017 & 0.042 \\
\hline 129. & Kahamlyka (29-33) & 818 & 2.438 & 0.175 & 0.412 \\
\hline 130. & Matrosova (27-1) & 232 & 1.248 & 0.094 & 0.212 \\
\hline 131. & Kahamlyka (33-35a) & 892 & 4.247 & 0.308 & 0.718 \\
\hline 132. & Dovzhenka (19-77) & 73 & 0.422 & 0.028 & 0.070 \\
\hline 133. & Dovzhenka (2-19) & 26 & 0.126 & 0.008 & 0.021 \\
\hline 134. & Honcharova & 20 & 0.156 & 0.010 & 0.026 \\
\hline 135. & Sosyury (46-35) & 22 & 0.172 & 0.011 & 0.029 \\
\hline 136. & Kahamlyka (35a-72a) & 867 & 4.444 & 0.320 & 0.750 \\
\hline 137. & Avtobazivska (7-2/9) & 290 & 2.987 & 0.232 & 0.511 \\
\hline 138. & Harazhna & 39 & 0.183 & 0.013 & 0.031 \\
\hline 139. & Kahamlyka (72a-82) & 840 & 3.518 & 0.250 & 0.593 \\
\hline 140. & Yevropeyska (68-86) & 1607 & 11.471 & 0.919 & 1.973 \\
\hline 141. & Heroes of the anti-terrorist operation (2a-46a) & 440 & 5.863 & 0.413 & 0.986 \\
\hline 142. & Lyali Ubyyvovk (3-23) & 51 & 0.369 & 0.025 & 0.061 \\
\hline 143. & Kropyvnytskoho bystreet (2a-22a) & 20 & 0.165 & 0.011 & 0.027 \\
\hline 144. & Kropyvnytskoho bystreet (3-38) & 19 & 0.170 & 0.011 & 0.028 \\
\hline 145. & Zalizna (2-34) & 52 & 0.422 & 0.029 & 0.071 \\
\hline 146. & Yevropeyska (102-104) & 1390 & 3.264 & 0.230 & 0.549 \\
\hline 147. & Stepovoho Frontu (2-24) & 940 & 6.594 & 0.479 & 1.115 \\
\hline 148. & Yevropeyska (108-120) & 1561 & 8.683 & 0.683 & 1.489 \\
\hline 149. & Mayakovskoho (1-32) & 22 & 0.141 & 0.009 & 0.023 \\
\hline 150. & Kustarnyy bystreet (1-9) & 15 & 0.053 & 0.004 & 0.009 \\
\hline 151. & Yevropeyska (120-124) & 1479 & 5.013 & 0.395 & 0.860 \\
\hline 152. & Tokarnyy bystreet (2-12) & 21 & 0.104 & 0.007 & 0.017 \\
\hline 153. & Yevropeyska (124 - 136) & 1438 & 5.346 & 0.443 & 0.926 \\
\hline 154. & Yevropeyska (136-144) & 1375 & 3.367 & 0.270 & 0.579 \\
\hline 155. & Velykotyrnivska (34-11) & 1498 & 12.944 & 1.010 & 2.216 \\
\hline 156. & Nikitchenka (9-2) & 339 & 4.702 & 0.349 & 0.798 \\
\hline 157. & Yuri Pobedonostsev Boulevard (9-12) & 256 & 2.059 & 0.155 & 0.350 \\
\hline 158. & Heroes of the anti-terrorist operation (114-116) & 405 & 1.533 & 0.127 & 0.265 \\
\hline 159. & Heroes of the anti-terrorist operation (116-118/24) & 174 & 1.150 & 0.085 & 0.195 \\
\hline 160. & Ohnivska (2a-14) & 240 & 3.236 & 0.247 & 0.552 \\
\hline 161. & Shchepotyev Boulevard (9-16) & 245 & 0.986 & 0.073 & 0.167 \\
\hline 162. & Kolektyvna & 242 & 2.335 & 0.165 & 0.393 \\
\hline 163. & Stanislavskoho (2/14-6) & 237 & 1.197 & 0.086 & 0.202 \\
\hline 164. & Bayana (128-96) & 690 & 5.246 & 0.420 & 0.902 \\
\hline
\end{tabular}




\begin{tabular}{|c|c|c|c|c|c|}
\hline $\begin{array}{c}\text { No. the } \\
\text { investigated } \\
\text { section of } \\
\text { the highway }\end{array}$ & $\begin{array}{c}\text { Name of the street (and number of buildings) on } \\
\text { which the section of the highway falls }\end{array}$ & $\begin{array}{l}\text { Hourly traffic } \\
\text { intensity on the } \\
\text { road section, } \\
\text { car/hour, }\end{array}$ & CO emission, $\mathrm{g} / \mathrm{s}$ & $\begin{array}{l}\mathrm{NO}_{2} \text { emission, } \\
\mathrm{g} / \mathrm{s}\end{array}$ & $\begin{array}{l}\text { CmHm emis- } \\
\text { sion, } g / s\end{array}$ \\
\hline 1 & 2 & 3 & 4 & 5 & 6 \\
\hline 165. & Arktychnyy bystreet (12a-8) & 633 & 3.398 & 0.266 & 0.582 \\
\hline 166. & Arktychnyy bystreet (12-24) & 540 & 1.929 & 0.150 & 0.330 \\
\hline 167. & Heroes of the anti-terrorist operation $(94-76 / 14)$ & 734 & 2.227 & 0.154 & 0.373 \\
\hline 168. & Kolektyvnyy bystreet (1-12) & 200 & 0.711 & 0.049 & 0.119 \\
\hline 169. & Hrebinky (120-95) & 117 & 0.285 & 0.020 & 0.048 \\
\hline 170. & Bayana (94-56) & 566 & 1.817 & 0.143 & 0.312 \\
\hline 171. & Heroes of the anti-terrorist operation (74-46a) & 450 & 1.744 & 0.142 & 0.301 \\
\hline
\end{tabular}

